\title{
The peculiarities of gene expression of medullary breast carcinoma tumor-associated antigens in different types of breast tumors
}

\author{
M. A. Shyian ${ }^{1,2}$, O. I. Kostianets ${ }^{1,2}$, O. Yu. Tsuvariev ${ }^{1}$, A. V. Stolyaruk ${ }^{1}$, \\ S. S. Antoniuk ${ }^{3}$, V. V. Filonenko', R. G. Kiyamova ${ }^{1}$ \\ ${ }^{1}$ Institute of Molecular Biology and Genetics, NAS of Ukraine \\ 150, Akademika Zabolotnoho Str., Kyiv, Ukraine, 03143 \\ ${ }^{2}$ Educational and Scientific Centre «Institute of Biology» \\ National Taras Shevchenko University of Kyiv \\ 64/13, Volodymyrs'ka Str., Kyiv, Ukraine, 01601 \\ ${ }^{3}$ Dnipropetrovs'k Clinical Oncological Center \\ 21, Kosmichna Str., Dnipropetrovs'k, Ukraine, 49100 \\ m.a.shyyan@gmail.com
}

\begin{abstract}
Aim. To investigate gene expression profile of human medullary breast carcinoma's tumor-associated antigens in different histological types of breast tumors. To analyze a correlation between alterations in gene expression level and induction of immune response against the cor responding antigens. Methods. Real-time polymerase chain reaction. Results. Differential gene expression profile of 6 (RAD50, HMGN2, RBPJ, PABPC4, BRAP, $D E K)$ medullary breast carcinoma tumor-associated antigens have been revealed in breast tumors of different histological types. Correlation between changes in tumor-associated antigens gene expression level and induction of immune response has not been found. Conclusions. The genes of human medullary breast carcinoma tumor-associated antigens with differential expression pro-file in different histological types of breast tumors are potential diagno- stic markers of breast cancer. Alteration of tumor-associated antigens gene expression level is not a prelude to an immune response against their corresponding protein products.

Keywords: medullary breast carcinoma, tumor-associated antigens, immunoreactivity.
\end{abstract}

Introduction. Breast cancer is the most widespread cancer type among women, remarkable for a high mortality rate and mostly presented by the tumors of epithelial origin - breast carcinomas (BCs). According to the histopathological features, there are three common types of tumors: invasive ductal breast carcinoma (DBC, $50-80 \%$ of all BCs), lobular breast carcinoma (LBC, 5-15\%) and medullary breast carcinoma (MBC, 1-7\%) [1]. This heterogeneity of malignant breast tumors testifies to the urgency of searching for new markers, required for the differential diagnostics and therapy of this disease.

It is known that during carcinogenesis the human immune system recognizes structurally altered, ampli-

\footnotetext{
(C) Institute of Molecular Biology and Genetics, NAS of Ukraine, 2012
}

fied or aberrantly expressed proteins (tumor-associated antigens - TAA) as foreign entities. This may induce cellular and/or humoral immune response [2]. The study on the nature of immunogenicity of these proteins as well as the determination of specific or differential profiles of [the] TAAs gene expression in different histological types of BC may become a basis for the elaboration of novel and more efficient approaches and means for diagnostics and therapy of breast cancer. Besides, it will expand current views on molecular mechanisms of malignant transformation and antitumor immune response [1].

The application of novel highly efficient technologies, in particular, phage display, SEREX (serological identification of antigens by recombinant expression cloning), SERPA (serological proteome ana- 
lysis), and protein microarrays as well as meta-analysis and scientific literature data allowed identifying a great number of potential tumor-associated antigens [3]. In our previous studies using the modified SEREX method we have also identified tumor-associated antigens of MBC [4]. However, their further application as probable diagnostic biomarkers of neoplastic diseases and targets for targeted tumor therapy should be defined in detail. In particular, [the] TAAs expression in different types of breast carcinomas and immunogenicity in cancer patients should be studied extensively, since presently it is not explicitly defined why some autologous proteins become autoimmune antigens in the course of tumor development. The majority of authors state that the humoral immune response is mostly directed to the proteins with altered concentration, while the share of proteins with antigen features acquired due to mutations is rather small $[2,5]$. This item requires additional investigations.

The aims of this work were, firstly, to study the expression patterns of genes encoding nine MBC-associated antigens in breast tumors of different histological types compared to conditional normal breast tissues of women with fibrocystic disease, using the real-time polymerase chain reaction (PCR) and, secondly, to define a possible relation between the changes in the level of gene expression and the induction of humoral immune response to their protein products.

Materials and Methods. Tissues and blood serum samples of patients. The surgical samples of normal and breast cancer tissues were obtained in 2009-2011 in the Dnipropetrovsk Clinical Oncological Center (Ukraine). The tissue samples were frozen in liquid nitrogen immediately after surgical extraction and kept until their application at $-70{ }^{\circ} \mathrm{C} .35$ breast carcinoma tissue samples were taken for study: invasive ductal carcinoma $(n=22)$, invasive lobular carcinoma $(n=8)$ and medullary carcinoma $(n=5)$. [The] Breast tissues of patients with the fibrocystic disease (FCD) $(n=5)$ were used as control (Table 1).

The histological type and grade of tumors were defined by the histological and immunohistochemical analysis (Dnipropetrovsk Clinical Oncological Center).

The sera of cancer patients and healthy donors were provided by the Dnipropetrovsk Clinical Oncological
Center and were used in the study (Table 1). The serum samples were obtained by the standard phlebotomy without anticoagulant and kept at $-20{ }^{\circ} \mathrm{C}$ with the addition of glycerol to $50 \%$.

The protocol of the study was approved by the Ethics committees of the Institute of Molecular Biology and Genetics NAS of Ukraine and the Dnipropetrovsk Clinical Oncological Center.

Real-time PCR. The extraction of total RNA, treatment with DNAse and synthesis of cDNA. The total RNA was extracted from the breast tumors and normal tissues samples by guanidine-thiocyanatechloroform method using the standard protocol [6]. The amount and purity of the extracted total RNA were defined using the Biomate 5 spectrophotometer (Thermo Electron, USA) and $1 \%$ formaldehyde-agarose denaturating gel-electrophoresis, respectively.

The aliquotes of total RNA ( $3 \mu \mathrm{g})$, extracted from the tissue samples, were treated with DNAse I according to the manufacturer's protocol (Fermentas, USA). The RevertAid Reverse Transcriptase Kit and oligonucleotide primers Oligo(dT)18 were used to synthesize cDNA in accordance to the standard manufacturer's protocol (Fermentas).

The real-time PCR was performed in iCycler iQ5 thermal cycler (Bio-Rad,) using SYBR Green I Master Mix 2 (Fermentas, USA). The amplification was performed with the following protocol: $95^{\circ} \mathrm{C}$ for initial denaturation $(60 \mathrm{~s})$ and 45 two-stage amplification cycles - denaturation at $95^{\circ} \mathrm{C}(10 \mathrm{~s})$ and hybridization of specific primers and their extension at $60^{\circ} \mathrm{C}(60 \mathrm{~s})$.

The homogeneity and specificity of PCR products were analyzed by electrophoresis in $1 \%$ agarose gel as well as by the presence of a sharp peak on the melting curves of reaction products.

The calculations of the relative expression of target genes normalized to the endogenous control and their comparison in different samples were performed by LinReg-Ct PCR method and Pfaffl's equation [7]:

Relative level of gene expression $=$

$$
=\frac{\left(E_{\text {ЦГ }}\right)^{\Delta C_{\text {ЦГГ (контроль- пухлина) }}}}{\left(E_{\text {РГ }}\right)^{\left.\Delta C t_{\text {РГ }} \text { (контроль- пухлина }\right)}}
$$

where $E_{T G}$ and $E_{R G}-$ PCR efficiency for the target and reference gene, respectively; $\Delta C t_{T G}$ - difference in 
Table 1 The characteristics of the samples of tissues and blood sera of patients and the control group

\begin{tabular}{|c|c|c|}
\hline \multirow{2}{*}{ Characteristics } & \multicolumn{2}{|c|}{ Number of samples } \\
\hline & Tissue & Blood serum \\
\hline \multicolumn{3}{|c|}{$\begin{array}{l}\text { Experimental group (for tissue samples: } 35 \text { patients, mean age (years) } S D 59.22 \pm 12.7 \text {, age range } 35-82 \text {; } \\
\text { for serum samples: } 132 \text { patients, mean age (years) } S D 51.49 \pm 17.2 \text {, age range 19-82) }\end{array}$} \\
\hline Invasive ductal breast carcinoma & 22 & 80 \\
\hline Invasive lobular breast carcinoma & 8 & 23 \\
\hline Medullary carcinoma & 5 & 9 \\
\hline Fibroadenoma & - & 20 \\
\hline Including tumors with known grade, $\%$ of the total: & 86 & 82 \\
\hline Grade 1 & 0 & 7,3 \\
\hline Grade 2 & 22,2 & 33,9 \\
\hline Grade 3 & 77,8 & 59,8 \\
\hline Including ER status of tumors, $\%$ & 76 & 52 \\
\hline Positive & 78,1 & 71,1 \\
\hline Negative & 21,9 & 28,9 \\
\hline Including PR status of tumors, $\%$ & 76 & 52 \\
\hline Positive & 62,5 & 61,5 \\
\hline Negative & 37,5 & 38,5 \\
\hline Including HER-2/neu status of tumors, $\%$ & 76 & 52 \\
\hline Positive & 31,3 & 30,8 \\
\hline Negative & 68,7 & 69,2 \\
\hline Including Ki-67 positive tumors, $\%$ & 43 & - \\
\hline Including tumors with lymph node status, $\%$ of positive tumors & 20 & 28,8 \\
\hline
\end{tabular}

Note. SD - standard deviation; ER - estrogen receptor; PR - progesterone receptor; FCD - fibrocystic disease.

$C t$ values, obtained for the target gene, between the control and tumor samples; $\Delta C t_{R G}-$ difference in $C t$ values, obtained for the reference gene, between the control and tumor samples. The mean values of the corresponding genes expression in five samples of breast tissues of the patients with FCD were used as the control.

Enzyme-linked immunosorbent assay. The enzyme-linked immunosorbent assay of the number of antibodies against the medullary breast carcinoma antigens in the sera of breast cancer patients and healthy donors was performed pursuant to the standard protocol [8]. Their recombinant analogues, obtained in our previous studies, were used as the antigens [8].
Statistical data processing. The level of the target gene expression in the tumor tissue sample was interpreted as changed - increased or decreased - if it was threefold higher or lower, respectively, [3, 9] than the mean relative expression level of the corresponding gene in the control group of conditional normal breast tissues of the patients with FCD according to the PCRanalysis data $[3,9]$. The reliable difference between the frequencies of detecting the cases with the changed gene expression in $\mathrm{BC}$ compared to conditional normal tissues was determined using Pearson's criterion $\left(\mathbf{Y}_{2}\right)$.

The serum samples were considered positive if the index of their optic density in the enzyme-linked im- 
Table 2

The characteristics of nine target antigens

\begin{tabular}{c|c|c}
\hline Antigen & Function & Properties \\
\hline RAD50 & $\begin{array}{c}\text { DNA double-strand break } \\
\text { repair[12] }\end{array}$ & $\begin{array}{c}\text { medullary breast } \\
\text { carcinoma } \\
\text { SEREX-antigens [10] }\end{array}$
\end{tabular}

FAM50A $\begin{gathered}\text { Unknown. Participation in } \\ \text { the cell cycle }\end{gathered}$
a

HMGN2

Chromatin remodeling

RBPJ

$$
\begin{gathered}
\text { Intercellular } \\
\text { communication of Notch } \\
\text { signaling pathway }
\end{gathered}
$$

PABPC4 Regulation of mRNA

translation and stability

CTSL1 Intracellular and extracellular proteolysis

DEK DNA replication and repair, mRNA splicing $[13,14]$

BRAP

$$
\begin{gathered}
\text { Nuclear import of } \\
\text { proteins [15] }
\end{gathered}
$$

$\mathrm{NaPi} 2 \mathrm{~b}$

Transport of inorganic phosphate into cells [16]

$$
\begin{aligned}
& \text { Most frequently } \\
& \text { encountered antigen } \\
& \text { in SEREX-antigen } \\
& \text { database }
\end{aligned}
$$

Breast cancer marker [17]

munosorbent assay [8] exceeded the cut-off value, defined as the mean value of the control sera of healthy donors with the addition of three standard deviations.

Bioinformatical analysis. The database of SEREXantigens of CID (Cancer Immunome Database, URL: http://ludwig-sun5.unil.ch/Cancer ImmunomeDB/) was used for bioinformatical analysis of SEREX- antigens.

The frequency of antigen detection in the cDNA database of CID was determined using Excel software (Microsoft Office, 2007).

Results and Discussion. The panel of nine target antigens, selected for the analysis. Nine target antigens were selected to study the expression profile in breast carcinomas of different histological types compared to normal breast tissues. The panel of nine target antigens (P9TA) contained seven potential MBC tumor-associated antigens (TAAs) (RAD50, FAM50A, HMGN2, RBPJ, PABPC4, CTSL1, DEK), which were selected on the basis of the phage allogenic screening of 41

MBC autoantigens [10] due to their reaction only with the blood sera of breast cancer patients [11]. BRAP and $\mathrm{NaPi} 2 \mathrm{~B}$ proteins were included in the analysis because of the elevated level of their genes expression in different tumors, including breast tumors (Table 2).

It should be noted that $\mathrm{NaPi} 2 \mathrm{~B}$ antigen is the target of therapeutic monoclonal antibodies MX35, which are under clinical trials for the treatment of ovarian carcinomas [16-19]. The detection of new sites of NaPi2B expression in tumors expands a possible application of MX35 antibodies for the therapy of patients with other types of cancer, breast cancer in particular.

The determination of the relative gene expression of target antigens at the mRNA level in different types of breast carcinomas using real-time PCR. Real-time PCR was used to determine the P9TA gene expression profile in different types of breast tumors and in non-tumor tissues.

The results of PCR-analysis are presented in Table 3 , namely, the number of $\mathrm{BC}$ samples and tissues of the patients with FCD with altered gene expression. It is noteworthy that the expression levels of all nine target antigens in the tissue samples of the patients with fibrocystic diseases did not exceed the established threshold, with the exception of one case of the decrease in SLC34A2 gene expression (Table 3).

The investigations demonstrated a significant difference in the expression levels of three genes (RAD50,DEK, BRAP) in BC compared to the breast tissues of the patients with FCD. We established that [the] $D E K$ gene expression was three times higher in $\mathrm{BC}$ compared to the control tissue and [the] expression of genes RAD50 and BRAP was three times lower in $\mathrm{BC}$ compared to the control tissue. This is in good agreement with the previously reported literature data, according to which the above-mentioned genes are directly or indirectly involved in carcinogenesis.

We have also analyzed the P9TA genes expression relative to the histological types of breast carcinomas (Table 4 and Fig. 1).

The comparative analysis of the expression of investigated genes in different histological types of BCs and in the tissues of patients with FCD allowed us to establish some group differences (Table 4). For instance, we have found a significant elevation of the expression levels of $D E K$ and $R B P J$ genes as well as a 
Table 3

The analysis of expression of nine target genes in breast carcinomas and tissues of patients with fibrocystic diseases (FCD)

\begin{tabular}{c|c|c|c}
\hline \multirow{2}{*}{ Gene } & \multicolumn{3}{|c}{$\begin{array}{c}\text { Number of tissue samples with altered mRNA expression } \\
\text { level }\end{array}$} \\
\cline { 2 - 4 } & \multicolumn{2}{|c}{$\mathrm{BC}(\mathrm{n}=35)$} & $\mathrm{FCD}(\mathrm{n}=5)$ \\
\cline { 2 - 4 } & Increased & Decreased & $\begin{array}{c}\text { Increased or } \\
\text { decreased }\end{array}$ \\
\hline RAD50 & 2 & $19 *$ & 0 \\
FAM50A & 16 & 6 & 0 \\
RBPJ & 15 & 1 & 0 \\
PABPC4 & 6 & 12 & 0 \\
HMGN2 & 4 & 10 & 0 \\
CTSL1 & 4 & 7 & 0 \\
DEK & $21 *$ & 2 & 0 \\
BRAP & 1 & $24 * *$ & 0 \\
SLC34A2 & 11 & 2 & One, reduced \\
\hline
\end{tabular}

Note. $* \mathrm{p}<0,05 ; * \mathrm{p}<0,01$.

Table 4

Profile of P9TA genes expression in breast carcinomas of different histological types

\begin{tabular}{|c|c|c|c|c|c|c|}
\hline \multirow{3}{*}{ Ген } & \multicolumn{6}{|c|}{ Number of breast carcinoma samples } \\
\hline & \multicolumn{2}{|c|}{$\operatorname{IDBC}(n=22)$} & \multicolumn{2}{|c|}{ ILBC $(n=8)$} & \multicolumn{2}{|c|}{$\operatorname{MBC}(n=5)$} \\
\hline & Increased & Decreased & Increased & Decreased & Increased & Decreased \\
\hline RAD50 & 1 & 8 & 1 & $7 *$ & 0 & $5^{*}$ \\
\hline FAM50A & 10 & 4 & 1 & 0 & 2 & 1 \\
\hline$R B P J$ & $13^{*}$ & 1 & 0 & 0 & 0 & 0 \\
\hline$P A B P C 4$ & 6 & 6 & 0 & $7 *$ & 0 & 0 \\
\hline$H M G N 2$ & 4 & 3 & 0 & $5^{*}$ & 0 & 1 \\
\hline CTSL1 & 3 & 6 & 0 & 1 & 0 & 0 \\
\hline$D E K$ & $14^{*}$ & 1 & 3 & 1 & $5^{*}$ & 0 \\
\hline$B R A P$ & 1 & $16^{* *}$ & 0 & $5^{*}$ & 0 & 2 \\
\hline SLC $34 A 2$ & 8 & 2 & 1 & 0 & 1 & 0 \\
\hline
\end{tabular}

Note. IDBC - Invasive ductal breast carcinoma; ILBC - Invasive lobular breast carcinomaк; $M B C-$ medullary breast carcinoma; ${ }^{*} \mathrm{p}<0,05$; $* * \mathrm{p}<0,01$.

reduction of the $B R A P$ gene expression level in ductal breast carcinomas compared to the normal breast tissues. A significant decrease in the expression level of four genes (RAD50, HMGN2, PABPC4 and BRAP) was detected in the patients with LBC. The decrease of $H M G N 2$ and $P A B P C 4$ expression was revealed only in this type of breast carcinoma. In medullary breast carcinoma a significant increasing in the expression level of $D E K$ gene and decreasing in the expression level of RAD50 gene compared to the control group were identified.

Therefore, using the quantitative PCR-analysis, we have established the differential expression profile for six out of nine studied genes (RAD50, HMGN2, RBPJ, $P A B P C 4, B R A P$ and $D E K)$ in different histological types of BC (Fig. 2).

The comparative analysis of the immune reactivity of blood sera of the breast cancer patients with recombinant MBC antigens and the expression level of the corresponding genes of these antigens in breast tumors of the autologous patients was performed. In our previous studies the presence of antibodies against antigens of $\mathrm{MBC}$, including RAD50, FAM50, HMGN2, PABC4 and RBPJ was examined in blood sera of the breast cancer patients and healthy donors using the enzyme-linked immunosorbent assay [8]. 

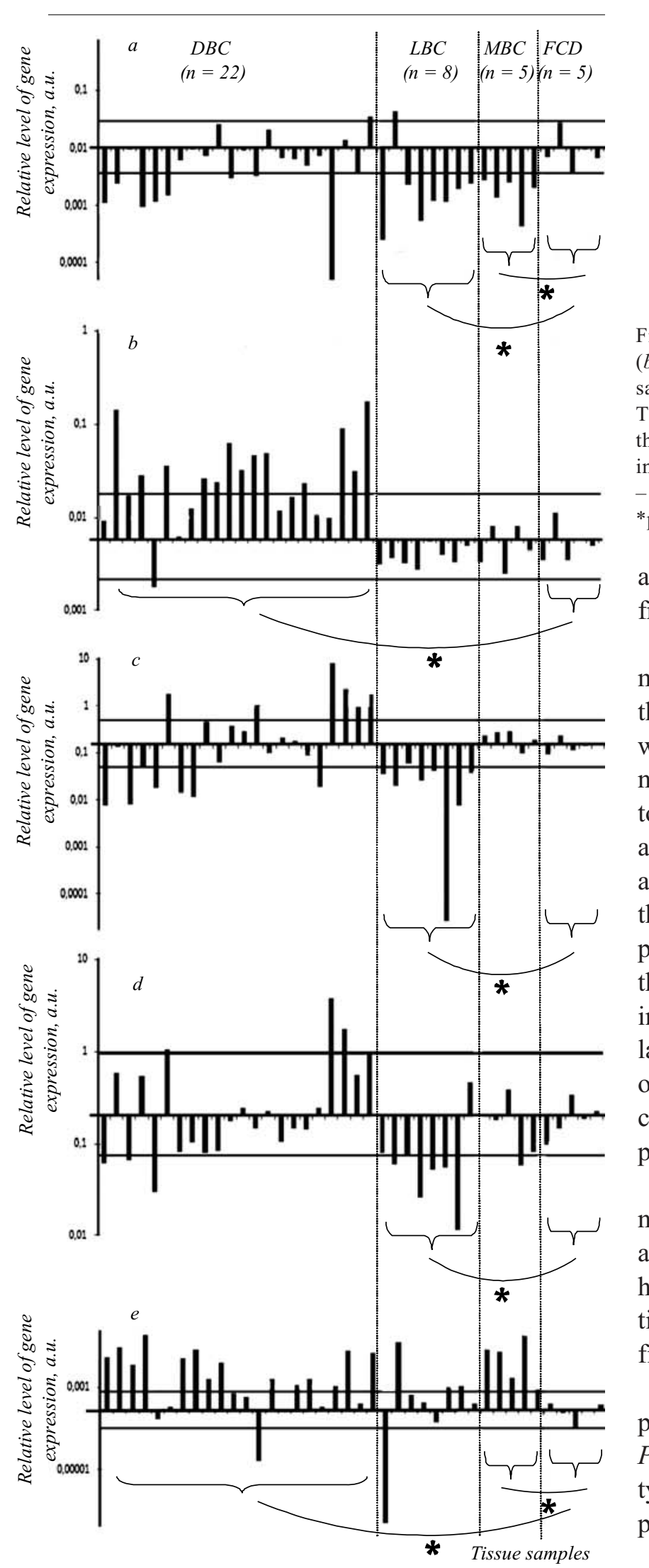

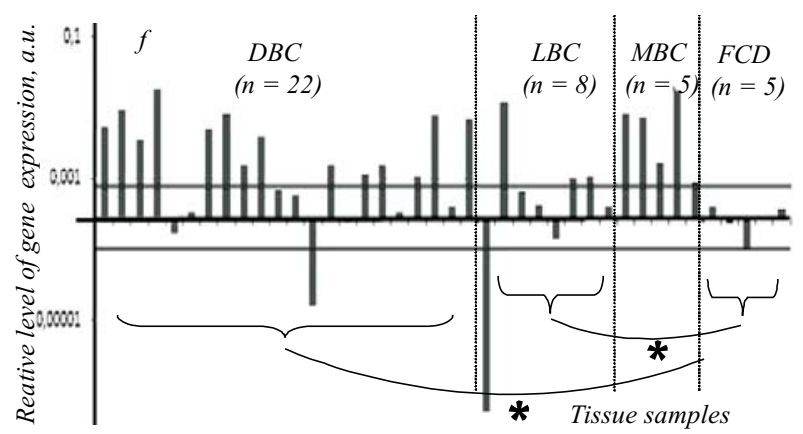

Fig. 1 The analysis of the target gene expression RAD50 (a), RBPJ (b), PABPC4 (c), HMGN2 (d), DEK (e) and BRAP ( $f$ ) in tumor samples of different histological types and control breast tissues. The mean value of the relative level for the target gene expression at the fibrocystic disease $(F C D)$ at each chart corresponds to the interception of $\mathrm{Y}$ - and $\mathrm{X}$-axes. $D B C$-ductal breast carcinoma; $L B C$ - lobular breast carcinoma; $M B C$ - medullary breast carcinoma; $* \mathrm{p}<0.05$

autologous tumor and blood sera samples, obtained from 17 breast cancer patients, were analyzed.

Regardless of several coincidences of positive immune response to the antigens RBPJ and RAD50 and the changes in the expression of their genes (Table 5), we can conclude that the altered genes expression does not correlate with the existence of the immune response to their correspondent antigens. Our data confirm the assumptions of the authors in the work [3] that the altered gene expression is not a mandatory prelude for the formation of immune response against their protein products [3]. The ultimate solution of the question on the reasons of TAAs immunogenicity requires the investigation of target antigens expression using a larger number of BC samples, as well as the assessment of protein abundance, as mRNA level does not always correlate with the amount of the corresponding protein product [20].

Therefore, we have demonstrated using the quantitative PCR method that three genes (DEK, RAD50 and $B R A P)$ out of nine SEREX-antigens investigated have significantly different expression levels in $\mathrm{BC}$ tissues compared to the breast tissue of patients with fibrocystic diseases.

We have identified the differential expression profile of six genes (RAD50, HMGN2, RBPJ, $P A B P C 4, B R A P$ and $D E K)$ in various histological types of breast carcinomas compared to the tissues of patients with FCD. 
The results of analysis of the SLC34A2 gene expression in different histological types of BCs testify to its increased expression in approximately one third of all breast carcinomas (11 out of 35 ) that is important for the determination of the breast cancer patients presumably sensitive to the therapy with MX35 monoclonal antibodies [16].

We have not established any direct correlation between the immune reactivity of five antigens (RAD50, FAM50A, HMGN2, RBPJ i PABPC4) in the sera of breast cancer patients and the altered expression

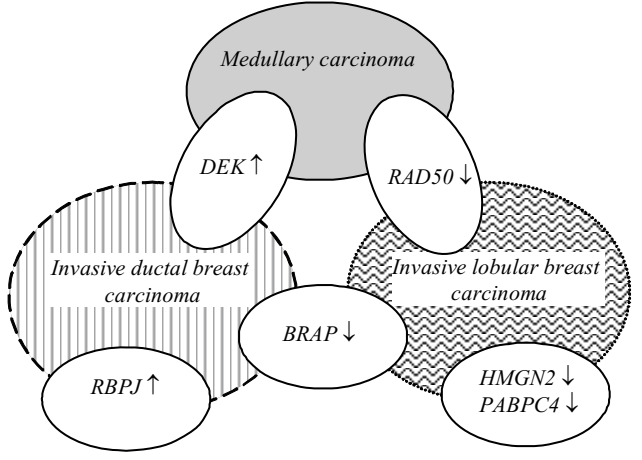

Fig. 2 Block-scheme of the differential expression profile of six genes in breast carcinoma of different histological types

Table 5

Comparative analysis of sera reactivity and gene expression of tumor-associated antigens in 17 autologous blood sera and tumor tissues samples of breast cancer patients

\begin{tabular}{|c|c|c|c|c|c|}
\hline \multirow{2}{*}{ Factor } & \multicolumn{5}{|c|}{ Antigen } \\
\hline & RAD50 & FAM $50 \mathrm{~A}$ & HMGN2 & RBPJ & PABPC4 \\
\hline Immune reactivity & $5 / 17$ & $0 / 17$ & $0 / 17$ & $2 / 17$ & $0 / 17$ \\
\hline Increased expression & $1 / 17$ & $6 / 17$ & $2 / 17$ & $4 / 17$ & $1 / 17$ \\
\hline Correlation with immune reactivity & $0 / 17$ & $0 / 17$ & $0 / 17$ & $1 / 17$ & $0 / 17$ \\
\hline Decreased expression & $7 / 17$ & $5 / 17$ & $6 / 17$ & $1 / 17$ & $7 / 17$ \\
\hline Correlation with immune reactivity & $2 / 17$ & $0 / 17$ & $0 / 17$ & $0 / 17$ & $0 / 17$ \\
\hline
\end{tabular}

level of their genes in the autologous breast tumors.

Therefore, the data obtained allow suggesting that the antigens RAD50, HMGN2, RBPJ, PABPC4, BRAP and DEK are potential diagnostic markers and possible targets for the therapy of certain cancer types, which requires further studies using different methodological approaches as well as a larger number of tissues samples taken from the patients with $\mathrm{BC}$ of certain histological types.

This work was supported by the National Academy of Sciences of Ukraine and the State Fund for Fundamental Research of Ukraine (grant No. F40.69-2011).

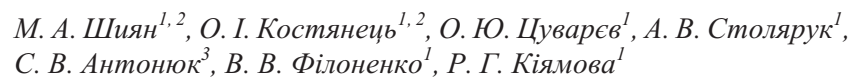

Особливості експресії генів пухлиноасоційованих антигенів медулярної карциноми молочної залози у різних типах пухлин молочної залози

${ }^{1}$ Інститут молекулярної біології і генетики НАН України Вул. Академіка Заболотного, 150, Київ, Україна, 03680
${ }^{2}$ ННЦ «Інститут біології» Київський національний університет імені Тараса Шевченка

Вул. Володимирська, 64/13, Київ, Україна, 01601

${ }^{3}$ Дніпропетровський клінічний онкологічний центр

Вул. Космічна, 21, Дніпропетровськ, Україна, 49100

Мета. Дослідити особливості експресії генів дев'яти пухлиноасочійованих антигенів медулярної карииноми молочної залози (МКМЗ) у пухлинах молочної залози різних гістологічних типів $i$ проаналізувати можливість існування кореляиії між змінами в рівні експресії генів та наявністю імунної відповіді проти відповідних антигенів. Методи. Полімеразна ланиюгової реакиіі у режимі реального часу. Результати. Виявлено диференційний профіль експресії шести (RAD50, HMGN2, RBPJ, PABPC4, BRAP $i$ $D E K)$ з дев 'яти досліджуваних генів у різних гістологічних типах пухлин молочної залози. Кореляції між змінами в рівні експресіі генів та наявністю імунної відповіді проти відповідних антигенів не встановлено. Висновки. Гени RAD50, HMGN2, RBPJ, PABPC4. BRAP i DEK антигенів МKMЗ, які мають диферен- иійний профіль експресії у різних гістологічних типах пухлин молочноі залози, є потенційними діагно- стичними маркерами раку молочної залози. Встановлено, щя зміна експресії досліджених генів не $\epsilon$ обо- в'язковою умовою виникнення імунної відповіді проти їхніх білкових продуктів.

Ключові слова: кариинома молочної залози, пухлиноасоиійовані антигени, імунореактивність. 
М. А. Шиян, О. И. Костянеи, О. Ю. Цуварев, А. В. Столярук,

С. В. Антонюк, В. В. Филоненко, Р. Г. Киямова

Особенности экспресии генов опухоле-ассоциированных антигенов медуллярной карциномы молочной железы в разных типах опухолей молочной железы

Резюме

Цель. Исследовать особенности экспрессии генов девяти опу холь-ассоциированных антигенов медуллярной карциномы молочной железы (МКМЖ) в опухолях молочной железы разных гистологических типов и проанализировать возможность существования корреляции между изменениями в уровне экспрессии генов и наличием иммунного ответа против соответствующчх антигенов. Методы. Уровень экспрессии генов изучали методом полимеразной цепной реакции в режиме реального времени. Результаты. Выявлен дифференциальный профиль экспрессии шести (RAD50, HMGN2, RBPJ, PABPC4, BRAP и DEK) из девяти исследуемых генов в различных гистологических типах опухолей молочной железы. Корреляции между изменениями в уровне экспрессии генов и наличием иммунного ответа против соответствующүих антигенов не обнаружено. Выводы. Гены RAD50, HMGN2, RBPJ, PABPC4, BRAP и DEK антигенов МКМЖ, имеюших дифференциильный профиль экспрессии в различных гистологических типах опухолей молочной железы, являются потенциильными диагностическими маркерами рака молочной железы. Установлено, что изменение экспрессии исследованных генов не является обязательным условием возникновения иммунного ответа против их белковых продуктов.

Ключевые слова: каричнома молочной железы, опухоль-ассоциированные антигены, иммунореактивность.

\section{REFERENCES}

1. Weigelt B., Reis-Filho J. S. Histological and molecular types of breast cancer: is there a unifying taxonomy? // Nat. Rev. Clin. Oncol..-2009.-6, N 12.-P. 718-730.

2. Brass N., Racz A., Bauer C., Heckel D., Sybrecht G., Meese E. Role of amplified genes in the production of autoantibodies // Blood.-1999.-93, N 7.-P. 2158-2166.

3. Scanlan M. J., Gout I., Gordon C. M., Williamson B., Stockert E., Gure A. O., Jager D., Chen Y. T., Mackay A., O'Hare M. J., Old L. J. Humoral immunity to human breast cancer: antigen definition and quantitative analysis of mRNA expression // Cancer Immun.-2001.-1.-P. 4.

4. Chen Y. T., Scanlan M. J., Venditti C. A., Chua R., Theiler G., Stevenson B. J., Iseli C., Gure A. O., Vasicek T., Strausberg R. L., Jongeneel C. V., Old L. J., Simpson A. J. Identification of cancer/testis-antigen genes by massively parallel signature sequencing // Proc. Natl Acad. Sci. USA-2005.-102, N 22.P. 7940-7945.

5. Rapberger R., Perco P., Sax C., Pangerl T., Siehs C., Pils D., Bernthaler A., Lukas A., Mayer B., Krainer M. Linking the ovarian cancer transcriptome and immunome // BMC Syst. Biol.2008.-2-P. 2.

6. Chomczynski P., Sacchi N. Single-step method of RNA isolation by acid guanidinium thiocyanate-phenol-chloroform extraction // Anal. Biochem.-1987.-162, N 1.-P. 156-159.

7. Pfaffl M. W. A new mathematical model for relative quantification in real-time RT-PCR // Nucleic Acids Res.-2001.-29, N 9.-e45.
8. Kostianets O. I., Shyian M. A., Antoniuk S. V., Demidov S. V., Filonenko $V$. V., Kiyamova R. G. Allogeneic screening of tumorassociated antigens of human breast cancer // Biotekhnologiya.2012.-5, N 4.-P. 55-64.

9. Scanlan M. J., Welt S., Gordon C. M., Chen Y. T., Gure A.O., Stockert E., Jungbluth A. A., Ritter G., Jager D., Jager E., Knuth A., Old L. J. Cancer-related serological recognition of human colon cancer: identification of potential diagnostic and immunotherapeutic targets // Cancer Res.-2002.-62, N 1.-P. 40414047.

10. Kiyamova R., Kostianets O., Malyuchik S., Filonenko V., Usenko V., Gurtovyy V., Khozayenko Y., Antonuk S., Old L., Gout I. Identification of tumor-associated antigens from medullary breast carcinoma by a modified SEREX approach // Mol. Biotechnol.2010.-46, N 2.-P. 105-112.

11. Kostianets O., Shyian M., Demidov S., Antoniuk S., Gout I., Filonenko V., Kiyamova $R$. Serological analysis of SEREX-defined medullary breast carcinoma-associated antigens // Cancer Invest.-2012.-30, N 7.-P. 519-527.

12. Bartkova J., Tommiska J., Oplustilova L., Aaltonen K., Tamminen A., Heikkinen T., Mistrik M., Aittomaki K., Blomqvist C., Heikkila P., Lukas J., Nevanlinna H., Bartek J. Aberrations of the MRE11-RAD50-NBS1 DNA damage sensor complex in human breast cancer: MRE11 as a candidate familial cancerpredisposing gene // Mol. Oncol.-2008.-2, N 4.-P. 296-316.

13. Privette Vinnedge L. M., McClaine R., Wagh P. K., Wikenheiser-Brokamp K. A., Waltz S. E., Wells S. I. The human DEK oncogene stimulates $\beta$-catenin signaling, invasion and mammosphere formation in breast cancer // Oncogene.-2011.-30, N 24.P. 2741-2752.

14. Riveiro-Falkenbach E., Soengas M. S. Control of tumorigenesis and chemoresistance by the DEK oncogene // Clin. Cancer Res.2010.-16, N 11.-P. 2932-2938.

15. Fulcher A. J., Roth D. M., Fatima S., Alvisi G., Jans D. A. The BRCA-1 binding protein BRAP2 is a novel, negative regulator of nuclear import of viral proteins, dependent on phosphorylation flanking the nuclear localization signal // FASEB J.2010.-24, N 5.-P. 1454-1466.

16. Yin B. W., Kiyamova R., Chua R., Caballero O. L., Gout I., Gryshkova V., Bhaskaran N., Souchelnytskyi S., Hellman U., Filonenko V., Jungbluth A. A., Odunsi K., Lloyd K. O., Old L. J., Ritter $G$. Monoclonal antibody MX35 detects the membrane transporter NaPi2b (SLC34A2) in human carcinomas // Cancer Immun.-2008.-8.-P. 3.

17. Lituiev D. S., Kiyamova R. G. Mutations in the gene of human type IIb sodium-phosphate cotransporter SLC34A2 // Biopolym. Cell.-2010.-26, N 1.-P. 13-22

18. Gryshkova V. S., Filonenko V.V., Kiyamova R. G. Inhibition of sodium-dependent phosphate transporter $\mathrm{NaPi} 2 \mathrm{~b}$ function with Mx35 antibody // Biopolym. Cell.-2011.-27, N 3.- P. 193-198.

19. Chen D. R., Chien S. Y., Kuo S. J., Teng Y. H., Tsai H. T., Kuо J. $H$., Chung J. G. SLC34A2 as a novel marker for diagnosis and targeted therapy of breast cancer // Anticancer Res.-2010.-30, N 10.-P. 4135-4140.

20. Gygi S. P., Rochon Y., Franza B. R., Aebersold R. Correlation between protein and mRNA abundance in yeast // Mol. Cell. Biol.-1999.-19, N 3.-P. 1720-1730. 